
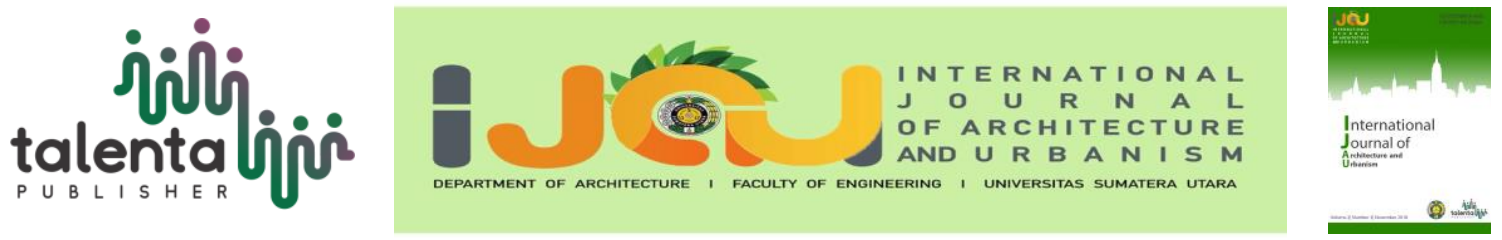

\title{
A Model of Revitalization at Pajak Ikan Lama, Medan
}

\author{
Dwi Lindarto Hadinugroho ${ }^{1^{*}}$, M. Ricky Alamsyah $S^{1}$ \\ ${ }^{1}$ Architecture Department, Faculty of Engineering, Universitas Sumatera Utara, Medan, Indonesia
}

\begin{abstract}
Abstrak: Revitalization is an effort to reproduce the values of an area that was once vital, but due to some reasons, it experienced degradation. This research discusses Pajak Ikan Lama as a revitalization area. There are two parts of scale in revitalization, namely macro level and micro level. Revitalization process in a neighborhood includes improvement of physical, economic, and social aspects. To undergo a revitalization, Pajak Ikan Lama needs improvement as well. The physical aesthetic of the area does not stand as the only solution to address this issue. It needs a series of equipment, with an escalation of the economy for the people as well as a recognition for the cultural value. This research used the qualitative method, also known as an artistic method because the process is emphasized in art, less patterned, and more likely to be interpretative. The collected data from the field is processed using interpretation. The result of this research found that most of the effort needed to revitalize the area lay on physical rearrangement, such as pedestrian, roadblock, welcome gate, street furniture, and street market.
\end{abstract}

Keyword: Pajak Ikan Lama, Pedestrian, Revitalization, Street Market.

\section{Introduction}

Medan is a city that has several heritage buildings. One of the primary locations of these buildings is in Kesawan area. These heritage buildings are built during the colonial era. Some of them remain strong up to today with richness in historical values. London Sumatra Office, Tjong A Fie Mansion, Tip-Top Restaurant, Medan Post Office, Bank of Indonesia, and Dharma Deli Hotel are some examples of heritage buildings in Medan. In Kesawan area, there is also a public market that the people call as Pajak Ikan Lama. The existence of these buildings was pioneered by Tjong A Fie, a Chinese businessman, who at first transferred his business activity from Labuhan Deli to Medan. The location of Pajak Ikan Lama is in between Stasiun Kereta Api street and Perniagaan street. Many traders and merchants fill the market space with clothes, fabrics, and souvenirs. The relatively close distance from Pajak Ikan Lama to the city center make it comfortable for local and international tourists to reach the market. However, the layout of Pajak Ikan Lama is severely unorganized, which then creates a slum impression. The roads that supposed to be functioning as a comfortable path for people to walk are currently used as parking lots, causing traffic jams in the market.

*Corresponding author at: Departement of Architecture, Faculty of Engineering, Universitas Sumatera Utara,

Jalan Perpustakaan Gedung J07, Medan 20155, Indonesia

E-mail address: dwilindarto@gmail.com 


\section{Literature Review}

Revitalization is an effort to reproduce the important values of an area or a part of a city that was once vital and lively, but due to some reasons, it experienced degradation. There are two parts of scale in revitalization, the macro level and the micro level. A revitalization process includes improvements in physical, economic, and social aspects. Revitalization approach must be able to recognize and utilize the potential of an environment, such as history, essence, uniqueness, and image [1].

Revitalization itself is not merely orienting in the physical beauty of a place. It needs a series of equipment with an escalation in the people's economy as well as a recognition for the existing cultural value. To undergo a revitalization, the people need to involve on it. The involvement at this point is not only participating to support the formal aspects, which formally require community involvement. It means engagement, where the community is not limited to those who are living in the area, but the community in a broader sense [2].

Before continuing further to the steps of revitalization, it is essential to pay more attention to the approach of doing it. As a fundamental definition, revitalization is an effort to regain the vitality of an area or a part of a city that was once lively, but due to some reasons, it experienced degradation. For that reason, revitalization is understood as an approach to improve the vitality of an area in a city. It includes rearrangement of land use as well as the renovation of existing structures. By doing this, it can develop the economic values and the social values of a revitalized area, improve the quality of the environment, and increase the land use utilization. The success of a revitalization approach in an area is influenced by social aspect and the area's characteristic which lays on the image of it, not in the idea or the applied concept without adjusting to the given environment. The revitalization approach based on the level, the nature, and the changing scale inside an area has several feasible operations, namely preservation/conservation, rehabilitation, and redevelopment.

\section{Methodology}

The research used qualitative methods. It is less patterned and known as an interpretative way because the result is more likely to be interpreted with the data collected from the field [3]. It aimed to describe the experience based on the real situation during the research period. The researchers collected data from observing the area and interviewing merchants as well as tourists. The research took place at several locations; Kereta Api street, Ahmad Yani 3 street, and Perniagaan street in the district of Medan Barat, Medan. Pajak Ikan Lama is one of the biggest textile markets in Medan. Below is the map of Medan's Kesawan area (Figure 1). 


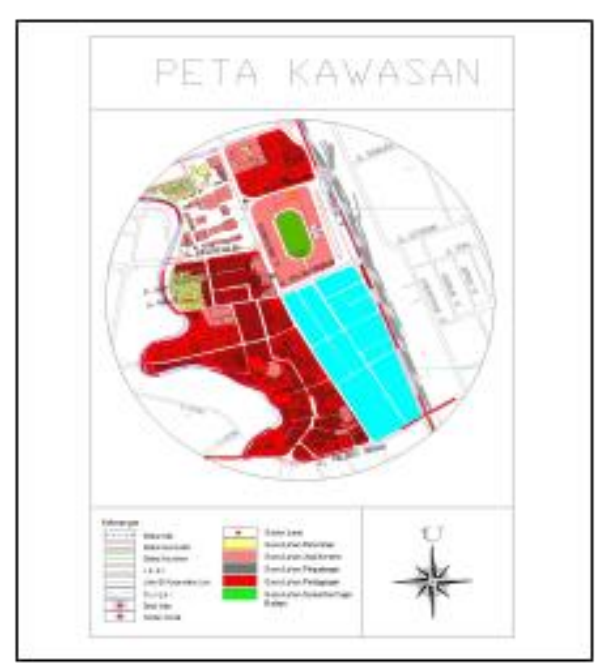

Figure 1. The Map of Research Area

\section{Result and Discussion}

\section{Lynch's Theory - Image of the City}

This theory describes the visual aspects in physical forms as well as the social aspects in a certain area, be it the function, the history, or the name. The image of the city can be seen and classified into five elements, namely paths, edges, landmarks, nodes, and districts [4].

\section{Path}

A path is the most vital element in a city's image. Kevin Lynch has found the justification for it based on this element. If the identity of a city's path is unclear, most people will eventually doubt the overall image of the city. A path consists of external access and internal access, which is the connecting roads between the city and the surrounding areas. The road network is the unification inside, where all activities are unified, and then resulting in the physical form of a city (Figure 2). Two-level and three-level shop-houses dominate the corridor in Ahmad Yani 3 street and Perniagaan street. These shop-houses are utilized commercially. Merchants who sell fabrics and clothes are present. The road in Ahmad Yani 3 street is \pm 6 meters in width, and the pedestrian width within this corridor is \pm 1.5 meters. The circulation of this corridor looks chaotic. Parking facility is not present in Ahmad Yani 3 street. Meanwhile, motorbikes are parked on the left and the right side of the road, which led to cause narrower space along this area (Figure 3 and 4). 


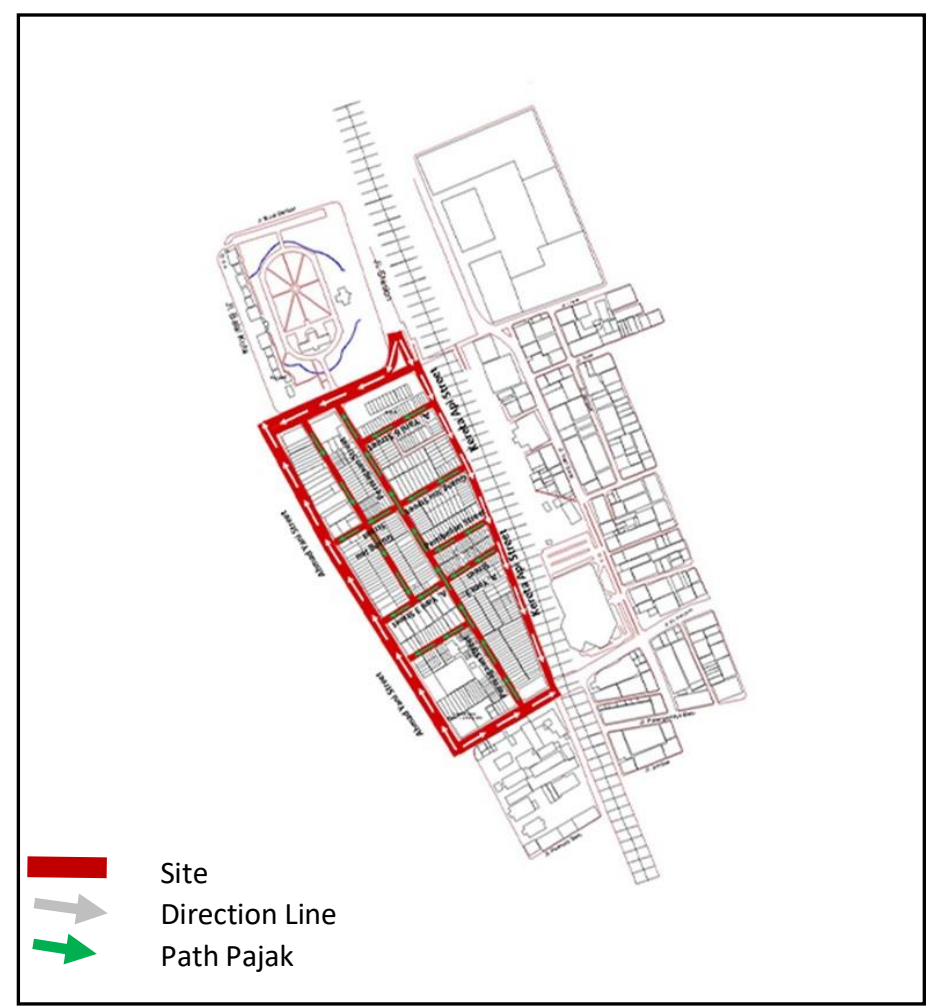

Figure 2. Map and Path Direction at Pajak Ikan Lama

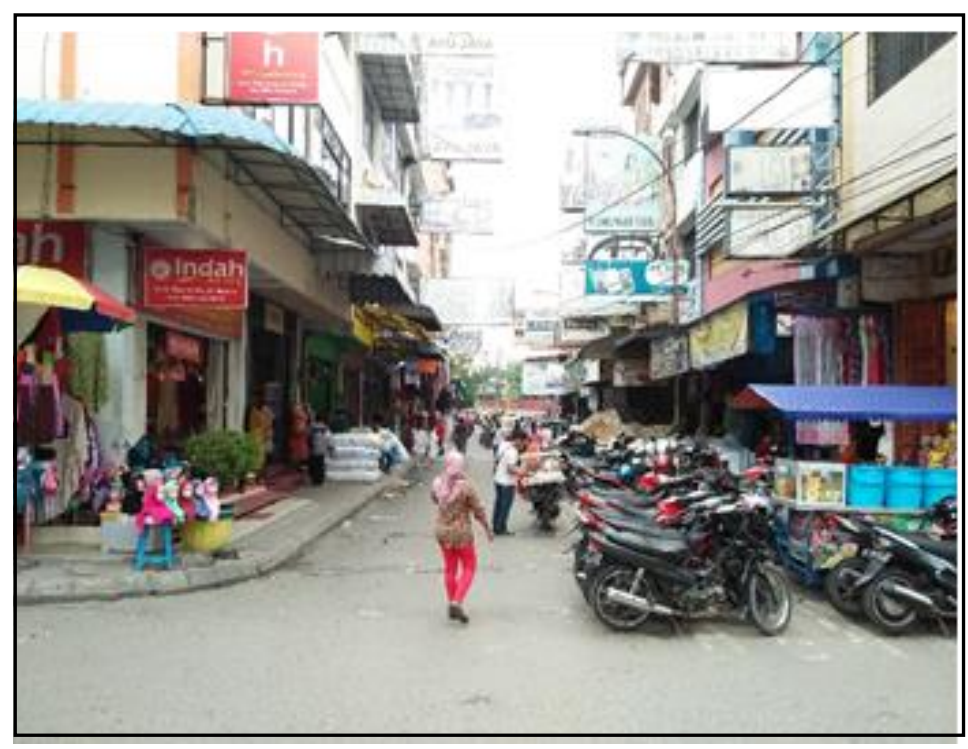

Figure 3. Elements of Path at Ahmad Yani 3 street 


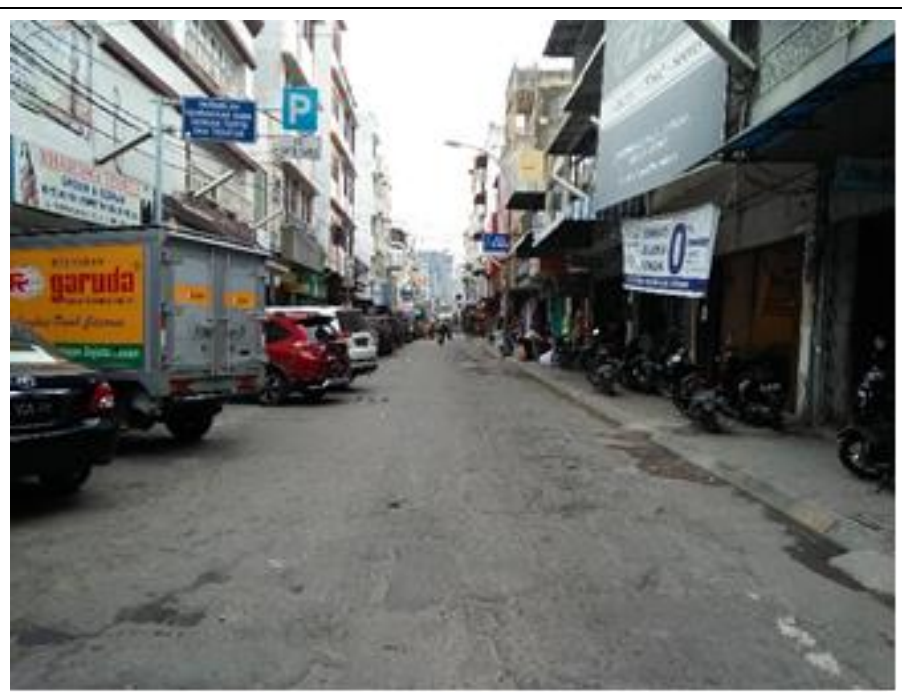

Figure 4. Elements of Path and the Circulation at Perniagaan street

\section{Edge}

Edge is the barrier between the two elements. In the corridor of Perniagaan street, a barrier dividing the pedestrian and the road is present. According to Lynch, the pedestrian and the road carry two different activities; while the pedestrian is determined for walkers whose purpose is to shop at Pajak Ikan Lama, the road itself is aimed for the traffic circulation (Figure 5). The present barrier between the pedestrian and the road in Perniagaan street is still functional, given the fact that there is no damage to the barriers along the corridor. However, the road is being used as parking lots, adding to the problems where the street merchants use the side roads as their market space as well. Also, the parking lots at the front of the shop-houses disturb the walkers to pass through this corridor (Figure 6). Despite the existing elements of the edge in this corridor, it is suggested to install additional materials such as lighting, park bench, garbage bin, and signage along the road. Planting vegetation as a barrier between the pedestrian and the road is also needed to improve the comfort of the market's dwellers in Pajak Ikan Lama (Figure 7 and 8).

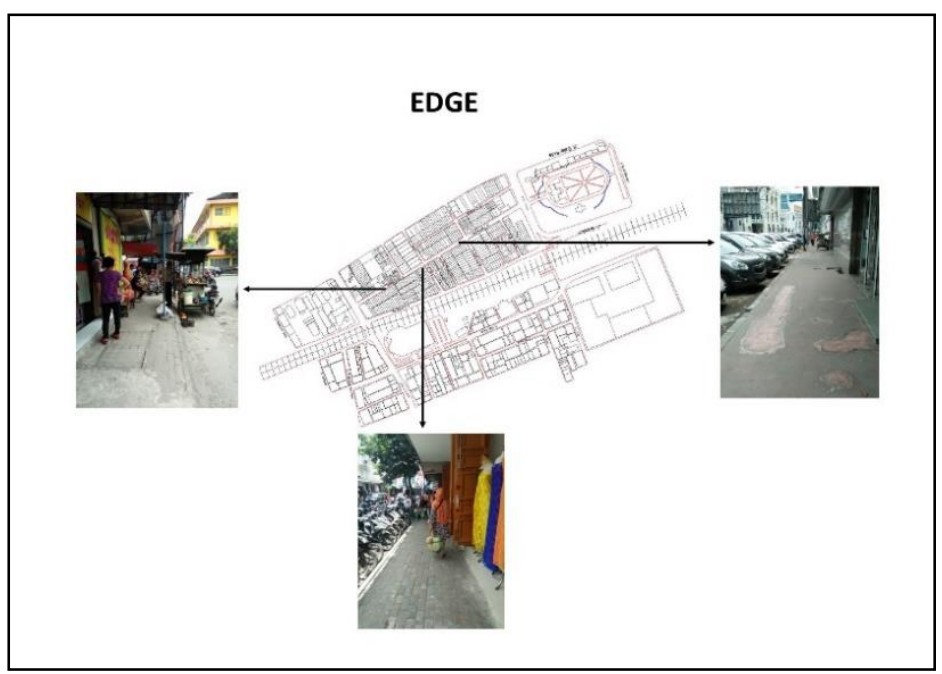

Figure 5. Elements of Edge at Perniagaan street - Pedestrian 


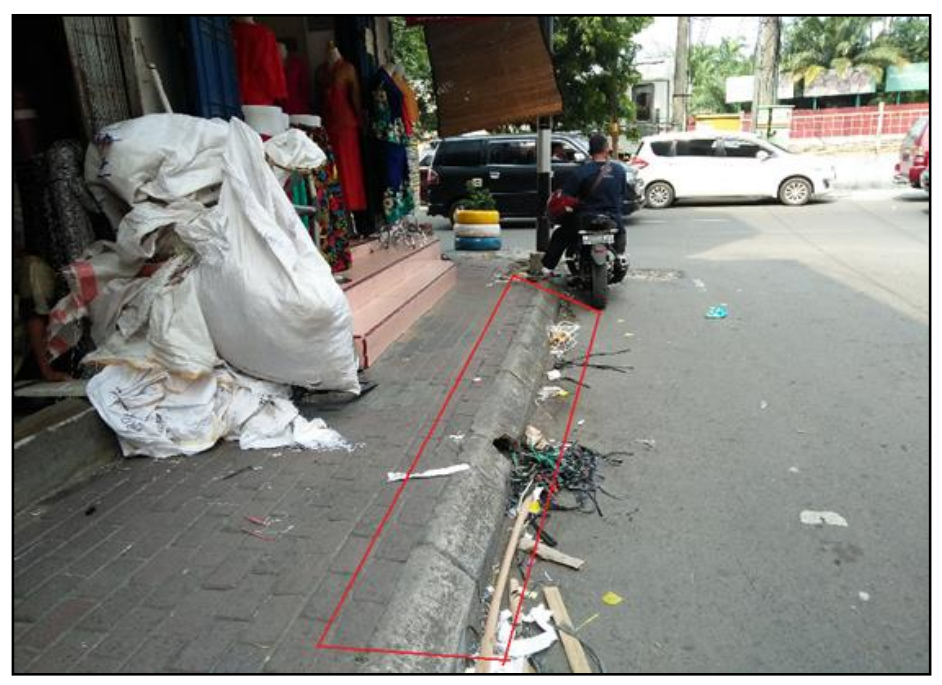

Figure 6. Elements of Edge at Perniagaan street - Roadblock and Drainage

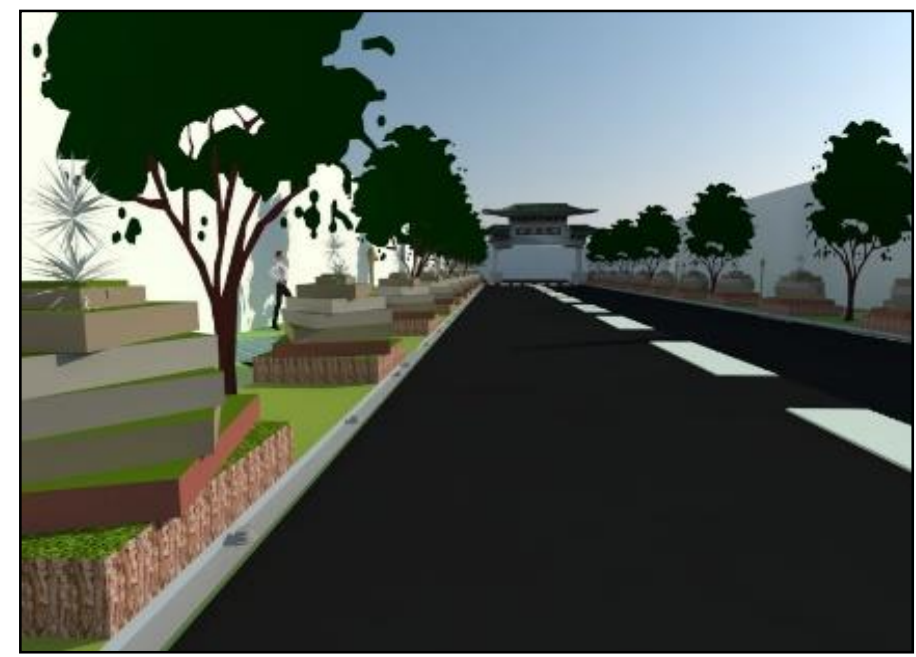

Figure 7: Design Elements of Edge, Roadblock, and Drainage in Perniagaan Street

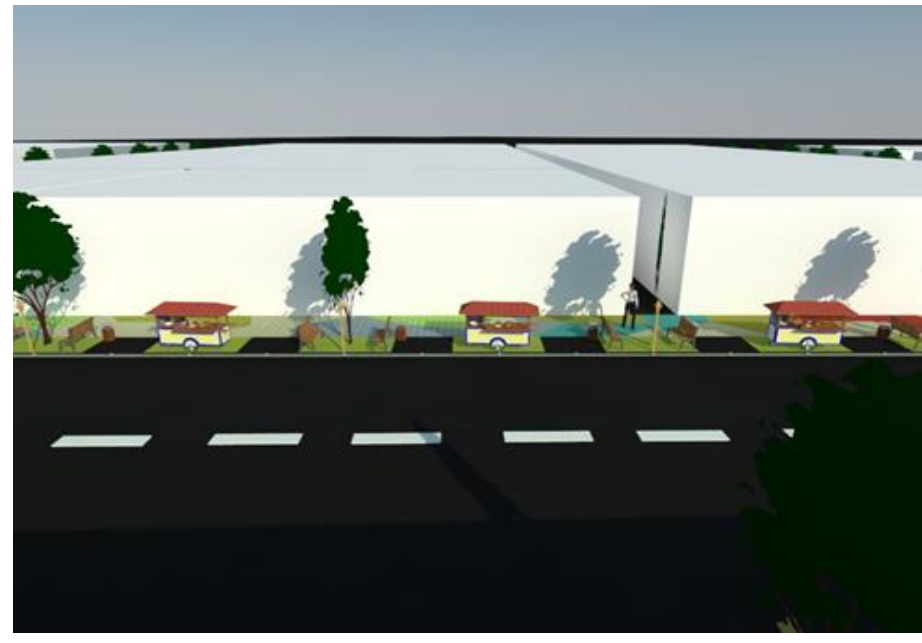

Figure 8. The Design for Edge's Element - Street Vendors 


\section{Landmark}

Landmark is one of the elements that can be used as an orientation tool for the people, given the easiness for people to notice the position of this element. A landmark can also be recognized as the icon or the identity of a city or an area. This element is generally defined as a building, a marker, a shop, or a mountain. There are four identified landmarks in the Pajak Ikan Lama area, namely Tjong A Fie Mansion, London Sumatra Office, Tip-Top Restaurant, and Merdeka Esplanade (Figure 9).

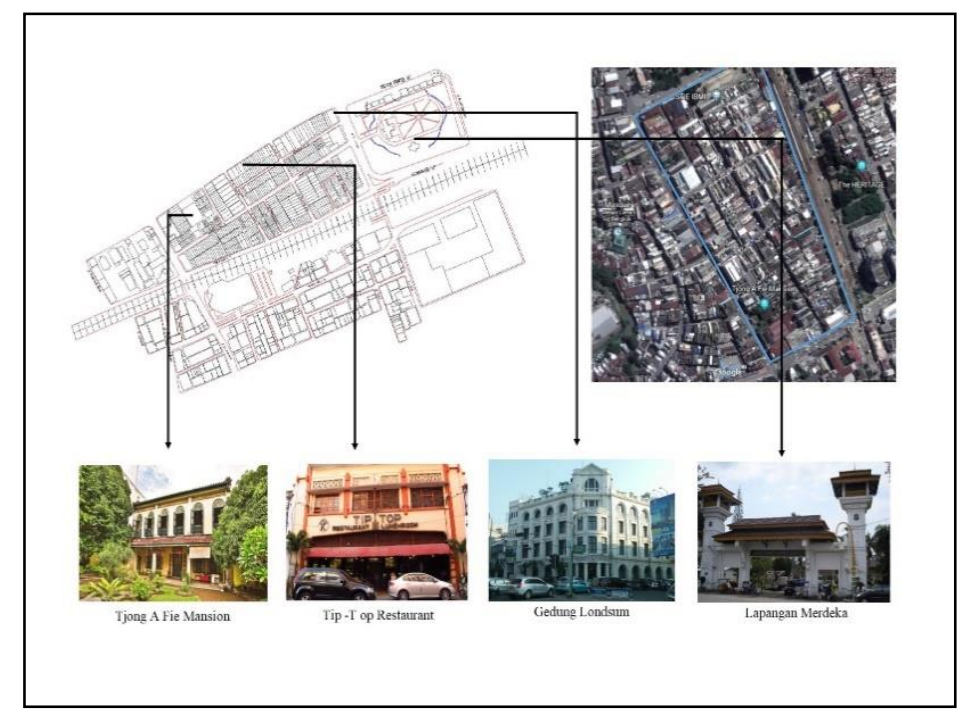

Figure 9. Historical Buildings in the Pajak Ikan Lama Area

\section{Node}

Node is a twist or a circle of strategic areas where direction and activities meet each other. This element can also be functioned as a link, a park, a crossing, and an intersection. Node is also present at Pajak Ikan Lama, located in the northern and southern part of Perniagaan street (Figure 10). This element, in the form of an intersection, is the center of activities at Perniagaan street. The location's proximity to Ahmad Yani 3 street is causing pedestrian and traffic crowd in the area. Perniagaan street is a meeting point of a few other roads with 8 meter in width. The nature of this road is a good indicator of a node. Furthermore, the trading activities which centered along this road have escalated the economy of the people (Figure 11). The next picture (Figure 12) illustrates the node concept at Pajak Ikan Lama. The design shows a welcome gate as the entry and exit point for the visitors of Pajak Ikan Lama. 


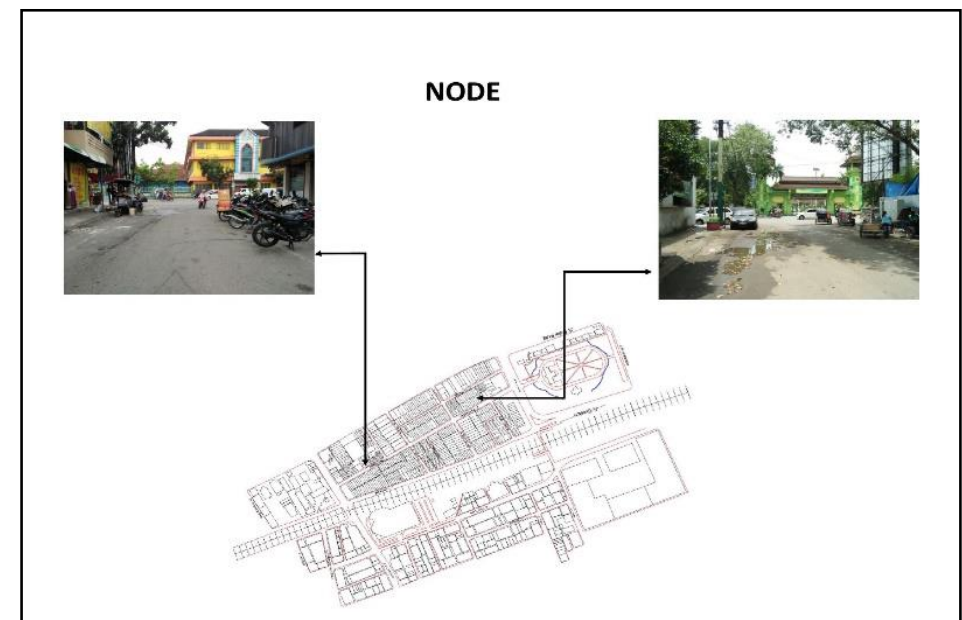

Figure 10. Elements of Node, Connecting the Intersection

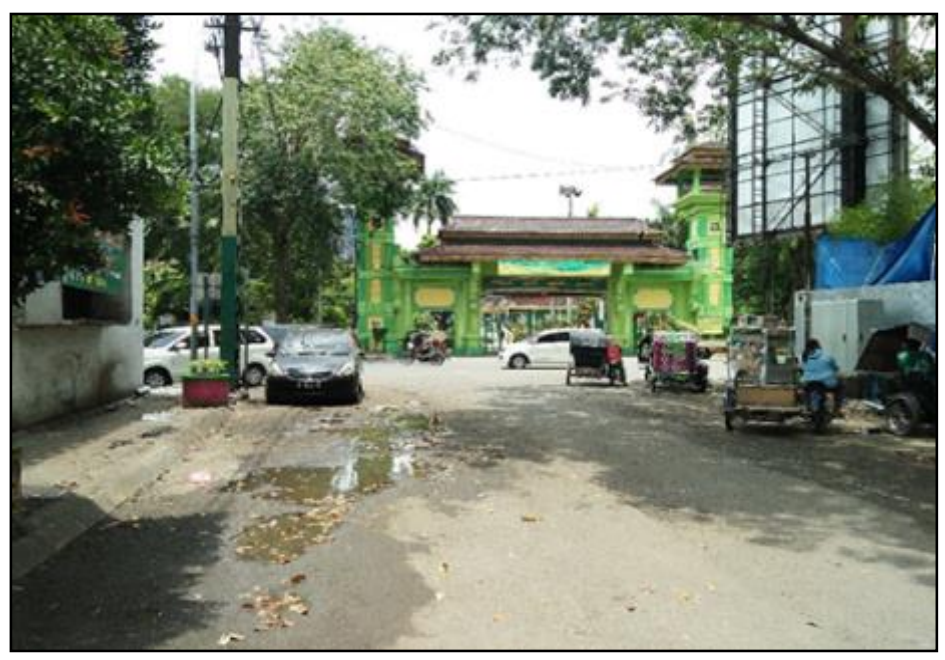

Figure 11. Elements of Node at Perniagaan street

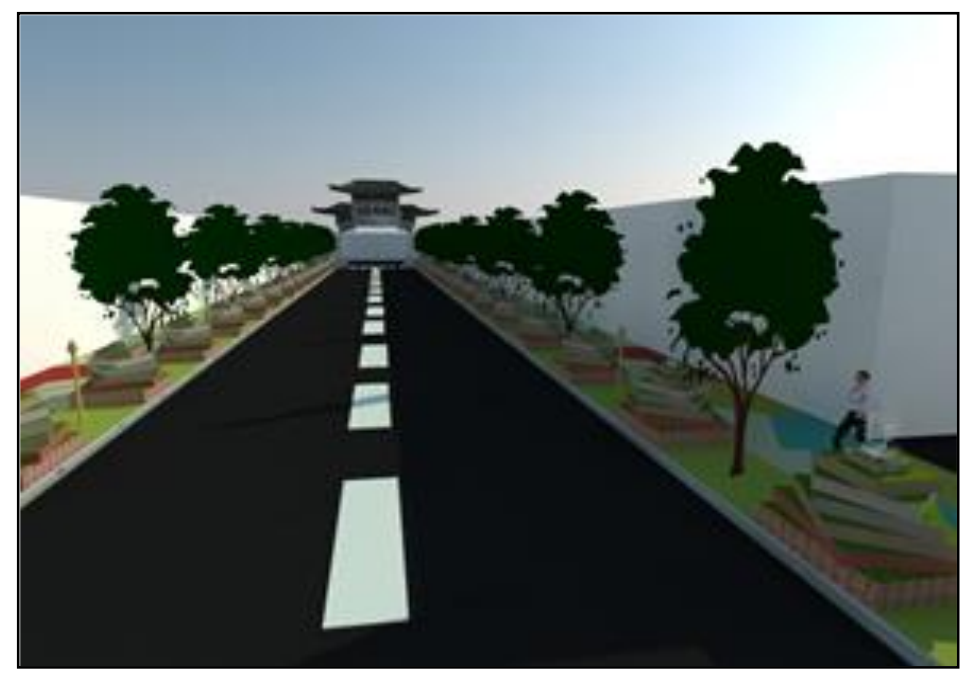

Figure 12. Design Elements of Node 


\section{District}

Pajak Ikan Lama is a district of the largest textile business in Medan. It occupies several blocks of shops and shop-houses in Perniagaan street, Ahmad Yani 3 street, Ahmad Yani 6 street, Guang Jou street, and Pembelian street. Aside from the textile business, many heritage buildings are also present in this area, namely Tjong A Fie Mansion, Tip-Top Restaurant, London Sumatra Office, and Merdeka Esplanade. The traffic around is overcrowded at some points. The business center is marked with multi-level buildings, traffic, and the presence of historical buildings (Figure 12).

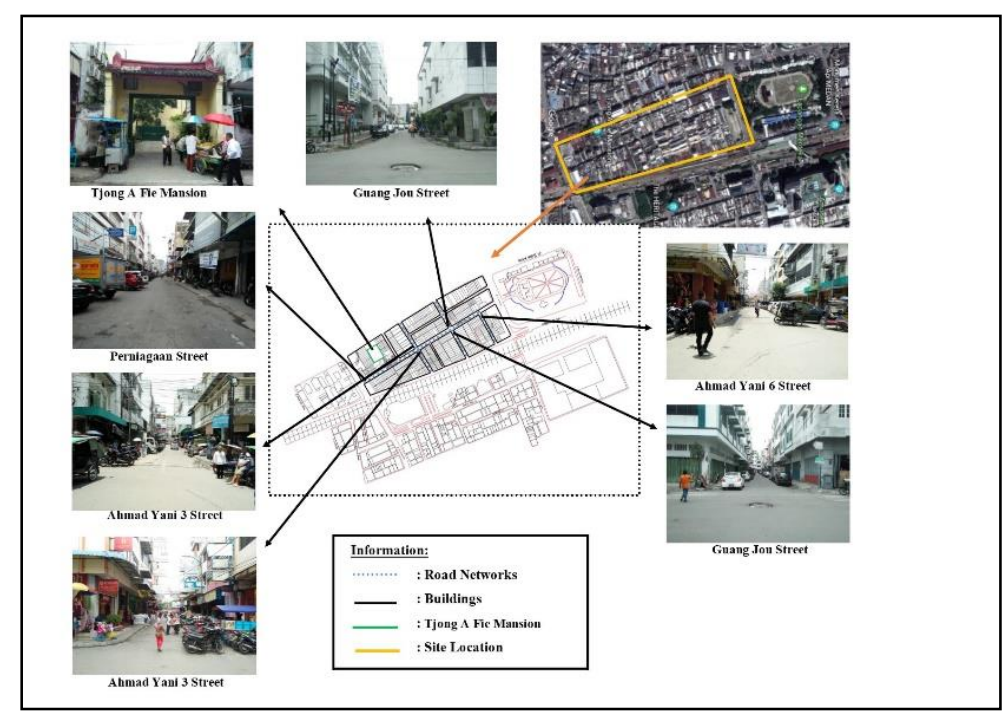

Figure 13. Map and the District of Pajak Ikan Lama

\section{Conclusion}

From the literature review and the discussion above, it can be concluded that the corridors that have a complete set of a city's image are Perniagaan Street, Ahmad Yani Street, and Guang Jou Street.

Perniagaan Street has Tjong A Fie Mansion (rear elevation) as its landmark. It works as a symbol with a unique form to assist people in placing themselves in the correct orientation as well as to help them in recognizing the area. It also has a path, which is the roads and the pedestrians as a link for circulation. Regarding the node, Perniagaan Street has several intersections, for example, the intersection between Perniagaan Street and Guang Jou Street and the intersection between Perniagaan Street and Ahmad Yani 3 Street. Regarding the edge, it has a barrier between the pedestrian and the road. Regarding the district, it is the biggest center of textile business in Medan. Ahmad Yani Street has landmarks namely Tjong A Fie Mansion (front elevation), Tip-Top Restaurant, and London Sumatra Office. Regarding the path, Ahmad Yani Street has a track and a pedestrian linking to Pajak Ikan Lama. Regarding the edge, it has some barriers between the pedestrian and the road, quite similar to Ahmad Yani 3 Street. Regarding the district, it is the business center for culinary, music, and sport. Tip-Top Restaurant and Baba Coffee are present in this corridor, as well as several stores which sell sports equipment and musical instruments.

Guang Jou Street has a path, represented by a road and a pedestrian. It also has a node, shaped by an 
intersection, connecting Guang Jou Street with Perniagaan Street. Regarding the edge, it has a barrier, separating the road with the pedestrian. Regarding the district, it is the business center for textile and curtain materials.

\section{Acknowledgment}

This article was written by researchers, partly funded by the University of North Sumatra and given as a contribution to the government to preserve and maintain revitalized historic buildings.

\section{REFERENCES}

[1] Danisworo, Pengertian Revitalisasi, URDI Vol. 13, 2002.

[2] Laretna, "Revitalisasi Kawasan Pusaka di Berbagai Belahan Bumi," p. 134, 2005 Maret.

[3] P. D. Sugiyono, Metode Penelitian Kombinas, Bandung: Alfabeta, 2011.

[4] K. Lynch, The Image Of The City, Amerika: The MITPress, 1960. 